\title{
State Practice
}

\author{
Editorially Noted by Anastasia Telesetsky \\ Department of Natural Resources and Environmental Science, California \\ State Polytechnic University San Luis Obispo, San Luis Obispo, \\ California, USA \\ ateleset@calpoly.edu
}

In this edition of the Asia Pacific Journal of Ocean Law and Policy, several important State practices are highlighted that demonstrate efforts to conform with international ocean law obligations. In Japan, Professor Chie Kojima highlights new statutory developments to improve Japan's response to illegal, unreported, and unregulated (IUU) fishing by banning the import of IUU seafood products through a December 2020 law. While the law has yet to be operationalized through regulation, it is an important step to improving collaboration across the global fishing chain to reduce potential markets for IUU products.

Dr. Arron Honnibal reports on recent announcements in Singapore in July 2021 to restart development at Pedra Branca/Pulau Batu Puteh including land reclamation. In light of the desire to maintain good relationships with its neighbouring States, the work will proceed in the spirit of transboundary cooperation including sharing and notifying relevant information about navigation and environmental impacts.

Professor Seokwoo Lee offers an important contribution querying the contemporary Korean response to search and rescue missions. He observes that in the past few years, Korean national maritime resources are regularly being used to respond to non-emergency salvage missions as part of institutional practice. He argues that non-emergency responses would be better led by the private sector because continuing the current practice may inadvertently undermine Korea's national responses to other maritime threats such as IUU fishing.

Professor Yubing Shi introduces the new Chinese Coast Guard law adopted in 2021 as well as scholarly critiques of the law. He argues that how the very new law will be applied by the Chinese Coast Guard will be refined over time with the development of an "Implementation Guide" by the Coast Guard and judicial practice from China's Supreme People's Court.

Finally, this State practice section offers two State legal developments from Indonesia and the United States. In Indonesia, Professor Arie Afriansyah observes that even though the government has acceded to the 
IMO International Convention on Standards of Training, Certification, and Watchkeeping for Fishing Vessel Personnel (sTCW-F), the domestic implementation of the treaty has been inconsistent. With competition between ministries for authority, it remains unclear how the sTCW-F will be uniformly and timely implemented. In the United States, questions of implementation delay had plagued the listing of critical habitat for endangered Humpback Whales under the Endangered Species Act and the Marine Mammal Protection Act. Critical habitat for several distinct populations of the iconic marine mammal were finally designated in April 2021, decades after the whales were listed as endangered. While some of the designated areas remain controversial among coastal users, the intent was to identify areas that covered the species ranges for important humpback whale prey. Taken together, the State practice in this volume reflects continued national commitment to implementing law of the sea obligations but also the ongoing challenges of domestic implementation. 